\title{
Persepsi Pengguna Kosmetik terhadap Tayangan Youtube Tasya Farasya
}

\author{
Agatha Christy Adriani, Septia Winduwati \\ Agatha.915160021@stu.untar.ac.id,septiaw@fikom.untar.ac.id
}

Fakultas Ilmu Komunikasi Universitas Tarumanagara

\begin{abstract}
in this era, customers are using social media, Youtube. They use beauty vlogger's content to make it easy for cosmetic users to get references based on reviews given by beauty vloggers. The development of cosmetics such as examples of Focallure Products. Focallure was updated by one of the vlogger's beauties, Tasya Farasya. This research was made to find out the perceptions created by Focallure cosmetics users on beauty vlogger on Tasya Farasya's Youtube. Theories used in this research are communication theory, social media theory and perception theories. This study uses qualitative considerations with descriptive characteristics. The results of the study show the fact of Focallure cosmetics users on the YouTube show Tasya Farasya is Tasya Farasya is a beauty vlogger that helps explain Focallure products by detailed and honest reviews in providing reviews. There are also internal and external factors that support the creation of this perception. Internal factors that support such as; Tasya Farasya has a beautiful face, has a special desire in cosmetology, good emotions when watching, and remembers that Tasya Farasya was once MUA. External factors such as; Tasya Farasya has a close relationship with Focallure, the lighting on the show is bright, the use of the background on the show is elegant and the number of subscribers provided by Tasya Farasya
\end{abstract}

Keywords: beauty vlogger, cosmetics, perception.

\begin{abstract}
Abstrak
Di era sekarang ini, para konsumen memanfaatkan media sosial yaitu Youtube. Mereka memanfaatkan konten beauty vlogger untuk memudahkan kalangan pengguna kosmetik untuk mendapatkan referensi berdasarkan ulasan yang diberikan oleh beauty vlogger. Perkembangan kosmetik seperti Produk Focallure. Produk Focallure diulas oleh salah satu beauty vlogger yaitu Tasya Farasya. Penelitian ini dilakukan untuk mengetahui persepsi yang tercipta dari pengguna kosmetik Focallure pada tayangan Youtube beauty vlogger Tasya Farasya. Adapun teori yang digunakan pada penelitian ini adalah teori komunikasi, media sosial dan persepsi. Penelitian ini menggunakan pendekatan kualitatif dengan metode deskriptif. Hasil penelitian menunjukkan bahwa persepsi dari pengguna kosmetik Focallure pada tayangan Youtube Tasya Farasya adalah Tasya Farasya merupakan beauty vlogger yang informatif dalam menjelaskan produk Focallure secara lengkap dan jujur dalam memberikan ulasan. Terdapat juga faktor internal dan eksternal yang mendukung terciptanya persepsi tersebut. Faktor internal yang mendukung seperti; Tasya Farasya dipandang paras yang cantik, memiliki kesamaan minat di bidang makeup, emosi yang baik pada saat menonton, dan mengingat bahwa Tasya Farasya pernah menjadi MUA. Faktor eksternal seperti; Tasya Farasya memiliki hubungan yang erat dengan Focallure, lighting pada tayangan tersebut terang, penggunaan background pada tayangan tersebut yang elegan dan jumlah subscriber yang dimiliki oleh Tasya Farasya.
\end{abstract}

Kata Kunci: beauty vlogger, kosmetik, persepsi. 


\section{Pendahuluan}

Komunikasi nyatanya sudah dipengaruhi oleh kehadiran media saat ini. Seiring berjalannya waktu, media berkembang menjadi berbagai jenis, salah satunya adalah media sosial yang seperti saat ini digunakan oleh hampir semua orang. Media sosial menurut Denis McQuail (2011)` adalah media telematika yang merupakan suatu alat teknologi yang berbeda dengan penggunaan yang berbeda pula.

Media sosial dapat menyentuh berbagai kalangan dari anak kecil hingga orang dewasa dan orang tua, hal ini dikarenakan media sosial mudah diakses dan dianggap praktis. Kemudahan yang didapat dan kecepatan penyebaran informasi melalui media sosial mengakibatkan media sosial berkembang dengan cepat. Menurut Baskoro (2009) Youtube merupakan situs video yang menyediakan berbagai informasi berupa 'gambar bergerak'. Situs ini disediakan bagi mereka yang ingin melakukan pencarian informasi video dan menontonnya langsung. Kita juga bisa berpartisipasi mengunggah video ke server Youtube dan membaginya ke seluruh dunia.

Youtube yang merupakan contoh dari sebuah media komunikasi baru yang sedang digemari oleh masyarakat yang didalamnya berisikan konten -konten berupa audio visual. Video - video tersebut dibuat oleh content creator di Youtube atau sering disebut dengan youtuber. Menurut Cecariyani dan Sukendro (2018) banyak pembuat video Youtube yang berlomba - lomba untuk bersaing kekreatifitasan dalam menciptakan konten yang diharapkan berhasil untuk menarik perhatian masyarakat. Hal ini dapat dilihat dari data Techinasia yang telah melakukan riset yaitu dengan lebih dari satu miliar pengguna per bulan di seluruh dunia-hampir sepertiga dari jumlah pengguna internet secara keseluruhan-Youtube merupakan salah satu platform online paling populer saat ini. Popularitasnya diproyeksikan akan terus meningkat seiring dengan jumlah pengguna. Bahkan, lembaga riset pasar Statista memprediksi bahwa jumlah penggunanya akan mencapai angka 1,8 miliar orang pada tahun 2021 .

Berdasarkan hasil data Techniasia, banyak orang yang menjadikan Youtube sebagai wadah mereka dalam menyalurkan kreativitasannya dalam membuat video, salah satunya adalah vlog. Vlog adalah singkatan dari video blog. Vlog memiliki banyak peminat dan juga berkembang menjadi berbagai jenis yaitu vlog komedi, vlog edukasi dan vlog kecantikan yang disebut beauty vlog. Beauty Vlog merupakan sebuah content yang didalamnya berkaitan erat dengan pembahasan tentang kecantikan, perawatan tubuh dan lain lain. Beauty vlogger merupakan seorang content creator tentang kecantikan dan perawatan tubuh yang dikemas melalui video lalu diunggah di Youtube. Dalam profesinya, seorang beauty vlogger membuat video melalui tutorial makeup, ulasan suatu produk dan lain lain

Di era sekarang ini, para konsumen semakin mahir dalam memanfaatkan berbagai media sosial salah satunya yaitu Youtube. Mereka memanfaatkan konten beauty vlogger untuk memudahkan kalangan pengguna makeup untuk mendapatkan referensi berdasarkan ulasan yang diberikan oleh beauty vlogger. Mereka para beauty vlogger dipercaya dapat menyampaikan informasi berbagai produk secara lengkap serta apa adanya dan tidak dibuat buat seperti iklan yang ada pada media konvensional yang cenderung dilebih lebihkan. Hal ini dapat dilihat dari hasil survei ZAP Beauty Index yang dilakukan pada bulan Agustus 2018 terhadap 17.889 perempuan Indonesia yang dikatakan bahwa berdasarkan presentasenya perempuan 
Indonesia lebih mempercayai beauty vlogger $(41,6 \%)$ dibandingkan beauty advisor $(25,7 \%)$ dan kawan terdekat konsumen $(38,1 \%)$.

Terlibatnya beauty vlogger sebagai media yang digunakan untuk mencari ulasan oleh pengguna kosmetik, peneliti melihat adanya suatu persepsi yang tercipta oleh pengguna kosmetik dengan menonton tayangan beauty vlogger terhadap produk yang digunakannya.Menurut Suranto (2010) Persepsi itu sendiri merupakan proses internal yang diakui individu dalam menyeleksi, dan mengatur simuli yang datang dari luar. Stimuli itu ditangkap oleh indra, secara spontan pikiran dan perasaan kita akan memberi makna atas stimulus tersebut. Secara sederhana persepsi bisa dikatakan sebagai proses individu dalam memahami kontak atau hubungan dengan dunia sekelilingnya.

Menurut Kemenperin, produk kosmetik semakin beragam pada tahun 2012 mengalami peningkatan sebesar 14 persen dari tahun ke tahun. Terdapat dari hasil data penjualan kosmetik pada tahun 2012 mengalami peningkatan sebesar 14 persen dari tahun sebelumnya sebesar 8,5 triliun rupiah menjadi 9,76 triliun rupiah Hal ini membuat para produksi kosmetik semakin banyak di pasaran dengan merek yang beragam, salah satunya produk kosmetik Focallure yang mulai ramai diperbincangkan sejak pertengah tahun 2017. Menurut Female Daily, produk Focallure di ramaikan oleh salah satu beauty vlogger yaitu Tasya Farasya yang mendapatkan banyak respon positif dari viewer-nya. Tasya Farasya merupakan beauty vlogger yang memulai karirnya sejak 2 tahun lalu yang sekarang telah memiliki subscriber sebanyak hampir 3 juta.

Peneliti tertarik untuk meneliti persepsi yang timbul pada pengguna kosmetik Focallure terhadap tayangan Youtube Tasya Farasya. Konsep persepsi menekankan pada stimuli para pengguna kosmetik setelah melihat tayangan Youtube Tasya Farasya sehingga penonton merasa terkesan dengan produk Focallure.

\section{Metode Penelitian}

Penelitian ini dilakukan untuk mengetahui persepsi pengguna kosmetik Focallure terhadap tayangan Youtube Tasya Farasya. Dalam penelitian ini, penulis menggunakan pendekatan kualitatif. Menurut Strauss, Cobin mengungkapkan bahwa penelitian kualitatif adalah metode penelitian yang menghasilkan penemuan penemuan yang tidak dapat dicapai dengan menggunakan prosedur statistik atau cara kuantifikasi lainnya (dalam Ruslan, 2010), Ruslan juga berpendapat bahwa penelitian kualitatif dapat digunakan untuk meneliti kehidupan masyarakat, peristiwa tertentu dan pergerakan-pergerakan sosial yang terjadi di dalamnya.

Menurut Nazir (2011). Penelitian deskriptif adalah studi untuk menemukan fakta dengan interpretasi yang tepat. Dalam desain deskriptif ini, termasuk desain untuk studi formulatif dan eksploratif yang berkehendak hanya untuk mengenal fenomena - fenomena untuk keperluan selanjutnya. Sedangkan metode pengumpulan data yang digunakan adalah wawancara dan studi kepustakaan.

\section{Hasil Temuan dan Diskusi}

\section{Persepsi Informan}

Persepsi menurut Pride, Ferrel mengungkapkan bahwa persepsi adalah segala proses pemilihan, pengorganisasian dan penginterprestasian masukan informasi, sensasi yang diterima melalui penglihatan, perasaan, pendengaran, penciuman dan 
sentuhan untuk menghasilkan makna (dalam Fadila, Lestari, 2013). Menurut Boyd, Walker dan Larreche mengungkapkan bahwa persepsi adalah proses dengan apa seseorang memilih, mengatur dan menginterpretasikan informasi (dalam Fadila, Lestari, 2016). Menurut Slameto (2010) pengertian persepsi adalah proses yang masuknya pesan atau informasi kedalam otak manusia, melalui persepsi manusia terus menerus mengadakan hubungan dengan lingkungannya. Hubungan ini dilakukan lewat inderanya, yaitu indera penglihat, pendengar, peraba, perasa, dan penciuman.

Pengguna kosmetik Focallure menerima pesan atau informasi yang diterima melalui penglihatan dan pendengaran untuk menghasilkan makna bahwa tayangan YouTube Tasya Farasya merupakan informatif dalam penjelasannya dan Tasya Farasya sendiri merupakan beauty vlogger yang honest review. .

\section{Proses - Proses Perseptual para informan}

Perkembangan perseptual merupakan proses pengenalan yang dimulai oleh individu terhadap lingkungan melalui gayanya dan menangkap maknanya dengan sensori panca indra mereka, kemudian dicerna dalam otak mereka. Perkembangan perseptual ini memiliki aspek dari luar, seperti faktor lingkungan dimana seseorang akan berkembang dengan segala aspek komunikasinya. Terdapat tiga proses perseptual menurut Kotler, Amstrong (2012) Atensi selektif, pengguna kosmetik Focallure menyaring informasi sebagai persepsi bahwa Tasya Farasya merupakan beauty vlogger yang jujur sehingga mereka menonton tayangan Youtube Tasya Farasya sebagai media yang digunakan untuk mendapatkan informasi tentang produk Focallure. 2)Distorsi selektif, pengguna kosmetik Focallure menerjemahkan bahwa dengan banyaknya jumlah subscriber yang dimiliki oleh Tasya Farasya pada akun Youtube-nya akan mendukung apa yang telah mereka percayai sebagai beauty vlogger yang jujur dan informative 3)Retensi selektif, pengguna kosmetik Focallure mempertahankan sikap mereka dengan cara tetap mengikuti perkembangan Tasya Farasya,

\section{Aspek - Aspek Persepsi yang Terbentuk}

Menurut Lestari, Fadila dalam (2013) mengungkapkan bahwa persepsi terdiri dari berbagai aspek adalah; 1)Seleksi, pengguna kosmetik Focallure memilih Youtube Tasya Farasya sebagai media yang digunakan untuk mendapatkan informasi tentang produk Focallure dibandingkan beauty vlogger yang lain 2) Organisasi, pengguna kosmetik Focallure membeli produk Focallure berdasarkan informasi yang diberikan oleh Tasya Farasya pada akun Youtube-nya, 3) Interpretasi, pengguna kosmetik Focallure memberikan makna bahwa informasi yang diberikan oleh Tasya Farasya tentang produk Focallure pada tayangan Youtube-nya yang berjudul Focallure One Brand Tutorial mengalami keserasian dengan apa produk Focallure yang dibelinya.

\section{Faktor yang Mendukung Persepsi Informan}

Menurut Walgito (2010) terdapat 2 faktor yang mempengaruhi persepsi, faktor tersebut adalah faktor internal dan faktor eksternal.

1. Faktor internal yang mendukung persepsi, yaitu faktor-faktor yang terdapat dalam diri individu yang mencakup beberapa hal antara lain: 
a. Fisiologis

Pengguna kosmetik Focallure mengakui paras wajah cantik yang dimiliki oleh Tasya Farasya melengkapi usahanya untuk menonton tayangan Youtube Tasya Farasya yang berjudul Focallure One Brand Tutorial dalam usahanya untuk mempersepsi Tasya Farasya pada tayangan tersebut.

b. Perhatian

Pengguna kosmetik Focallure menangkap berbagai rangsangan pada Youtube Tasya Farasya yang berjudul Focallure One Brand Tutorial. Indera penglihatanya menangkap warna yang ada pada video dan gambar dari produk Focallure dan teknik makeupnya ya sehingga mereka tertarik dengan produk Focallure, sedangkan indera pendegarannya menangkap suara Tasya Farasya untuk memperkuat informasi tentang produk Focallure

c. Minat

Pengguna Kosmetik Focallure pada tayangan Youtube Tasya Farasya memiliki memiliki minat dibidang makeup sehingga Informan memperhatikan secara jelas tayangan Youtube Tasya Farasya yang berjudul Focallure One Brand Tutorial

d. Kebutuhan yang Searah

Informan sedang mencari penjelasan produk Focallure, untuk menjawab kebingungannya dengan caara menonton tayangan Youtube Tasya Farasya yang berjudul Focallure One Brand Tutorial

e. Pengalaman dan Ingatan

Pengguna kosmetik Focallure paa tayangan Youtube Tasya Farasya memiliki ingatan bahwa Tasya Farasya pernah menjadi MUA (Makeup Artist). Menurutnya MUA lebih mengerti tentang makeup. Ingatan tersebut masuk pada stimuli untuk mengingat ingatan tersebut ketika ia sedang mau mencari referensi makeup.

f. Suasana Hati

Pengguna kosmetik Focallure paa tayangan Youtube Tasya Farasya memiliki keadaan emosi yang baik sehingga membuat Informan menerima reaksi yang baik juga setelah menonton tayangan Youtube Tasya Farasya.

2. Faktor Eksternal yang mendukung persepsi, merupakan karakteristik dari lingkungan dan obyek - obyek yang terlihat di dalamnya. Elemen - elemen tersebut dapat mengubah sudut pandang seseorang terhadap dunia sekitarnya dan mempengaruhi bagaimana seseorang merasakannya atau menerimanya. Sementara itu faktor-faktor eksternal yang mempengaruhi persepsi adalah:

a. Ukuran dan Penempatan Dari Objek atau Stimulus

Pengguna kosmetik Focallure menyatakan bahwa Tasya Farasya sangat jelas dalam menjelaskan produk Focallure pada tayangan Youtube yang berjudul Focallure One Brand Tutorial. Dikatakan bahwa semakin besar hubungan yang dimiliki oleh Tasya Farasya dengan produk Focallure, maka semakin dalam pengetahuan Tasya Farasya untuk menjelaskan kembali tentang produk Focallure pada Focallure One Brand Tutorial.

b. Warna dari ObJek - Objek

Pengguna kosmetik Focallure menangkap informasi yang mereka dapat tentang produk Focallure didukung oleh lighting dari tayangan Youtube Tasya Farasya yang berjudul Focallure One Brand Tutorial. 
c. Keunikan dan Kekontrasan Stimulus

Pengguna kosmetik Focallure berpersepsi bahwa Tasya Farasya merupakan beauty vlogger yang elegan pada tayangannya, seperti yang berjudul Focallure One Brand Tutorial yang menggunakan background berwarna ungu bling - bling

d. Intensitas dan Kekuatan dari Stimulus

Pengguna kosmetik Focallure berpersepsi bila intensitas video Tasya Farasya seperti Focallure One Brand Tutorial lebih dipercaya tingkat aktualitasnya dengan jumlah penonton yang banyak.

e . Motion atau Gerakan

Pengguna kosmetik Focallure berpersepsi bahwa gerakan tangan yang dilakukan oleh Tasya Farasya pada video Focallure One Brand Tutorial mendukung penjelasan produk Focallure yang dijelaskan oleh Tasya Fasraya pada tayangan YouTube Tasya Farasya sehingga mendukung persepsi yang dicipakannya yaitu informative.

\section{Media Sosial sebagai Platform Informasi}

Menurut Dijk (2013) mengungkapkan bahwa media sosial adalah adalah platform media yang memfokuskan pada eksistensi pengguna yang memfasilitasi mereka dalam beraktivitas maupun berkolaborasi, Karena itu media sosial dapat dilihat sebagai medium (fasilitator) online yang menguatkan hubungan antar pengguna sekaligus sebagai sebuah ikatan sosial (dalam Nasrullah, 2016). Berbagai definisi, Nasrullah (2016), menyimpulkan bahwa Media Sosial merupakan medium di internet yang penggunanya dapat merepresentasikan dirinya maupun berinteraksi, bekerjasama, berkomunikasi dengan pengguna lainnya, dan membentuk ikatan sosial secara virtual. Dari berbagai pengertian digaris bawahi bahwa media sosial mempunyai ciri khas tertentu dalam kaitannya setiap manusia melakukan hubungan sosial di zaman perkembangan teknologi komunikasi. Sehubungan dengan hal itu, maka, Nasrullah (2016), Media sosial merupakan salah satu platform yang muncul di media siber, Karena itu, media sosial yang ada tidak jauh berbeda dengan karakteristik yang dimiliki oleh media siber.

Menurut Baskoro (2009) Youtube merupakan situs video yang menyediakan berbagai informasi berupa 'gambar bergerak' dan bisa diandalkan. Situs ini memang disediakan bagi mereka yang ingin melakukan pencarian informasi video dan menontonnya langsung. Masyarakat juga dapat berpartisipasi mengunggah video ke server Youtube dan membaginya ke seluruh dunia.

Pengguna kosmetik Focallure menggunakan Youtube sebagai media informasi untuk mereka mendapatkan informasi yang lengkap dan jelas tentang produk Focallure.

\section{Simpulan}

Persepsi yang terjadi oleh pengguna kosmetik Focallure terjadi karena masuknya berbagai informasi yang diberikan oleh Tasya Farasya pada tayangan Youtubenya sehingga munculah makna bahwa tayangan Tasya Farasya informative dan merupakan beauty vlogger yang informatif.

Persepsi ini timbul didukung dengan adanya faktor internal dan ekternal. Faktor internal yang mendukung pengguna kosmetik Focallure karena mereka merupakan pecinta kosmetik maka terjadi kemudahan untuk menerima informasi 
yang diberikan seputar kosmetik pada Youtube Tasya Farasya. Sedangkan faktor eksternal terjadi karena Tasya Farasya yang memiliki informasi mendalam terkait kosmetik Focallure yg didukung oleh estetika videonya.

\section{Ucapan Terimakasih}

Peneliti mengucapkan terimakasih kepada narasumber yang telah memberikan kesempatan dan menyempatkan waktu dalam konteks berbagi informasi mendalam. Peneliti mengucapkan terimakasih yang tertuju untuk para dosen yang telah membimbing, membina dan mengarahkan dalam penyusunan skripsi. Peneliti juga mengucapkan terimakasih kepada teman - teman yang telah memotivasi dan membantu dan menemani dalam penyusunan skripsi ini.

\section{Daftar Pustaka}

Baskoro, Adi. (2009). Panduan Praktis Searching di Internet. Jakarta: PT TransMedia

Fadila, Dewi dan Sari Lestari Zainal Ridho.(2013) .Perilaku Konsumen. Palembang: Citrabooks Indonesia

Gunawan, Imam. (2014). Metode Penelitian Kualitatif, Teori dan Praktik. Jakarta: Bumi Aksara.

Kotler, Philip and Kevin Lane Keller. (2012). Marketing Management 13. New Jersey: Pearson Prentice Hall, Inc

Nasrullah, Rulli. (2016). Media Sosial Perspektif Komunikasi, Budaya, Sosioteknologi, Cet.kedua.Bandung: Simbiosa Rekatama Media.

Nazir, Mohammad. (2011). Metode Penelitian. Jakarta: Ghalia Indonesia:

Ruslan, Rosady. (2010). Metode Penelitian : Public Relations dan Komunikasi. Jakarta: PT. RajaGrafindo Persada.. 